\title{
INFLUENCE OF RISK ASSETS IMPAIRMENT ON PERFORMANCE OF NIGERIAN LISTED DEPOSIT MONEY BANKS
}

\author{
Adewale Joel Adebisi (ACTI, MBA,M.Sc.,FCA) \\ Eco Bank Nigeria Limited, Nigeria \\ E-mail: jadebisiadewale@gmail.com \\ Adeyemi Wasiu Alabi (M.Sc., ACA) \\ Connect Marketing Services Limited, Nigeria \\ E-mail: yemmyalabi@gmail.com \\ Kolawole Fatimehin (MBA, ACA) \\ Eco Bank Nigeria Limited, Nigeria \\ E-mail: kolawolefatimehin@gmail.com
}

\begin{abstract}
Profitability is critical to the survival of Nigerian deposit money banks which is consistently been eroded by the impaired risk assets. Hence, this study was conducted to examine influence of risk assets impairment on performance of Nigerian deposit money banks. The specific objectives of the study were to; (i) determine the effect of impairment loss on operating profit; (ii) analyze effect non-performing loans ratio affect return on assets of Nigerian deposit money banks. Secondary data were collected and analysed using fixed and random effect regression analysis methods from a sample of 14 listed Nigerian deposit money banks. The study revealed that impairment loss, have significant negative relationship with operating profit $(\beta=2.294, p<0.01)$ and non-performing loan ratio have significant positive relationship with return on assets $(\beta=0.067, p<0.1)$. However, other variables such as inflation, liquidity and gross domestic product per capital also have effect on banks performance. The study concluded that risk assets impairment has significant negative influence on performance and that inflation, liquidity and gross domestic product have negative impact on profitability, while bank size has positive impact on profitability. The study recommended that; bank directors should put effective risk assets impairment test in place to boost reported profitability; the bank management should ensure effective management of liquidity ratio to boost return on equity; government policymakers should ensure that banks are mandated to disclose their risk assets impairment and expand their size by extending banking services to the unbanked areas.
\end{abstract}

Keywords: Assets Impairment, Risky Assets, Bank Profitability, Non-Performing Loans.

\section{Background to the Study}

\section{INTRODUCTION}

Profitability is critical to the performance and survival of any business entity globally. However, since the last global financial crisis, banking sector performance has not been stable, due to large value of bad loans and impairment of performing ones. Ahmed, Raiz, \& Muhammad (2012) 
concluded that banks with low loan loss provisioning are discovered to be more safer with chances of higher profitability. In last decade merger and acquisition of some Nigerian banks had taken place, while banks like Oceanic Bank, Intercontinental Bank, Afribank, Platinum and Habib Bank, Equatorial Trust Bank, Spring Bank, First Inland Bank lost their identity in that process (Nigeria Deposit Insurance Corporation, 2011); and most recently Skye Bank and Diamond Bank were aquired by another banks. However, the central bank governor issued a statement on another proposed recapitalization of Nigerian banks in 2019 which is likely to bring another merger or acquisition to meet the apex banks demand on new capitalization of deposit money banks in Nigeria.

According to Aboh (2011), majority of those banks failed mainly because of over impaired risk assets and high non-performing loan in their statement of financial statement, hence Nigerian banking system opted for IFRS adoption in line with global standard in 2012 to facilitate adequate financial reporting. However, the impact of this collapse was terribly felt by many citizens of Nigeria, because many employees lost their jobs, as productivity level of the existing ones shrank.

Consequently, CBN (2010) in a circular objected to banks practice of rescheduling nonperforming loan without taking borrowers' repayment capacity into consideration. This circular was used to eliminate banks practice of earning interest on loans that are already impaired, without any reasonable provision for such impairment. In IAS 36, an impairment loss is recognised to the extent the carrying amount of the asset exceeds its recoverable amount. For assets carried at historical cost, impairment losses are recognised as an expense immediately in the statement of profit or loss (Ernst \& Young, 2012).

\section{Statement of the Problem}

The problem of risk assets impairment on Nigerian banking profitability is a critical issue that should be addressed, considering the role of profitability in banking survival. Despite the various reforms, restructuring and recapitalisation in the Nigerian banking sector, the industry's performance is still very poor and yet to get it right with impairment loss reporting, level of nonperforming loans and bank size due to collapse of some of the banks. The situation is worrisome and several studies such as Idris (2014); Ozurumba (2016); Ebenezer, Omar and Kamil (2017), were carried out to assess the remote cause(s) of the collapse of the banks. The regulatory bodies such as Central Bank of Nigeria (CBN), Nigeria Deposit Insurance Corporation (NDIC), 2011 and Assets Management Corporation of Nigeria (AMCON) have also been working ceaselessly to ensure that depositors' funds are safe and to reduce risk assets impairment in other to have sound financial system. Authors such as Olaleye, Agboola, Solomon and Oyerogba (2014) investigated financial reporting and compliance of impairment of non-current assets, while studies of Ozurumba (2016), Tarko (2015), Kimathi (2014) focused on non perfoming loan, loan loss provisioning and how it affects profitability or performance.

In the developed countries, several studies were equally carried out by Hami, George and Peter (2013); Sooriyakumaran and Velnampy (2014); Bussoli, Conca, Gigante and Madaro (2016) on impairment of assets, though the studies did not focus on risk assets impairment, and how it affects variable such as profitability. These studies were carried out in foreign countries with different culture, language, and legislation. Therefore, findings from previous studies proved insufficient to gain insight into risk assets impairment accounting, and its effect on profitability in Nigerian deposit money banks. Hence, the interest in carrying out this study. 


\section{Research Questions}

This study attempts to answer the questions stated below:

1. In what ways would impairment loss affects operating profit of deposit money banks in Nigeria?

2. To what extent does non-performing loans affect return on assets of deposit money banks in Nigeria?

\section{Objectives of the Study}

The general objective of this study is to investigate the influence risk assets impairment have on the profitability of deposit money banks in Nigeria.

The specific objectives of the study are to:

1. Determine the effect of impairment loss on operating profit of deposit money banks in Nigeria 2. Analyse the effect of non-performing loans on return on assets of Nigerian deposit money banks.

\section{Hypotheses of the study}

The null hypotheses $\left(\mathrm{H}_{0}\right)$ formulated are:

$\mathrm{H}_{01}$ : Impairment loss does not have any significant effect on operating profit of Nigerian deposit money banks.

$\mathrm{H}_{02}$ : Non-performing loan does not have significant influence on return on assets of Nigerian deposit money banks.

\section{Significance of the Study}

There is awareness among the researchers and policy makers that risk assets impairments contributed to failure of many banks in Nigeria; there is quest for researches to be done on "assets impairment. However, there are only few researches on "assets impairment" available in Nigeria and companies need sensitization to pay a special attention on IAS 36 . The companies have to maintain accounting information that is reliability and relevance to the stakeholders. Therefore, this study addresses the problem of impairment loss, bank size, and non-performing loans in related to how they affect performance of deposit money banks in Nigeria. Findings from this study will add to relevant literatures on impairment accounting and performance in Nigerian deposit money banks. In addition, the study will serve as empirical basis that provide insight to risk asset impairment for accountants, auditors, audit committee, regulatory authorities, bankers, investors, investment analysts, researchers, policy makers and other stakeholders.

\section{Scope of the Study}

The research study analysed the influence of risk assets impairment on the profitability of Nigerian selected deposit money banks. The study dealt with variables such as impairment loss, nonperforming loan, return on assets, liquidity ratio, gross domestic product, inflation, bank size, return on equity and operating profit. This study focussed on banking sector, covered a period of six years from 2012 to 2017, due to the fact that IFRS was adopted in the year 2012 in Nigeria, and for easy comparison and data availability. 


\section{Theoretical Review}

\section{LITERATURE REVIEW}

Three theories are considered as underpinning this study. They are: Agency Theory, Frictional Theory, and Legitimacy Theory.

\section{Agency Theory}

Jensen and Meckling (1976) identified agency relationship as a contract under which one or more persons (the principal(s) engage another person (the agent) to perform some services on their behalf which involves delegating some decision-making authority to the agent. The authors noticed that if both parties are utility maximizers (opportunistic behaviour); a good reason exists to believe that the agent will not always act in the best interests of the principal. These researchers further explained that owners have interest in maximizing the value of their shares, whereas managers are more interested in private consumption of firm resources and firm growth, which make managers to be more concerned about high profitability. Agency theory has made us to understand that management of the organisations is assigned to an agent, hence the agent needs to report assets impairment in the financial statement for appropriate stewardship and for the business owners to know the quality of their assets. This theory ensure that risk assets impairment are properly reported, to ensure that reported profitability is accurate and reliable for decision making by the shareholders.

\section{Frictional Theory}

According to frictional theory there exists a normal rate of profit which is a return on capital that must be paid to the owners of capital as a reward for saving and investment of their funds rather than to consume all their income or hoard them. In a static economy where no unanticipated changes in demand or cost conditions occur, in long-run equilibrium the firms would be earning only normal rate of profit or loss on their capital and entrepreneurial talent.

Thus, according to frictional theory, economic profits or loss exist for some time because of frictional factors which prevent an instantaneous adjustment of the system to the new conditions. In line with this theory, manager needs to understand the implication of frictional issue on loan granted to customers and accounted for impairment where necessary using expected loss or actual loss approach in compliance with IAS 36 on disclosure of assets impairment. The aim of this is to ensure that profit is not accounted as earned on in value recorded is not more than the recoverable amount. Hence, this theory is equally relevant to this study.

\section{Legitimacy Theory}

According to Deegan and Unerman (2006), legitimacy theory asserts that organizations continually seek to ensure that they are perceived as operating within the bounds and norms of their respective societies, that is, they attempt to ensure that their activities are perceived by outside parties as being legitimate. Legitimacy theory relies upon the conception of a social contract between the organization and the society in which it operates. The concept is used to represent the multitude of implicit and explicit expectations that society has about ways the organization should conduct its operations. Legitimacy theory is one example of many theoretical perspectives, adopted in explaining and predicting accounting practice. The essence is about information disclosure, accountability, value relevance and the information need of users. Legitimacy theory could also be signalled as an explanation of the need for an independent opinion on the truth and on the fairness of the company's reporting. 
In line with theory, regulatory authority such as Central Bank of Nigeria, NDIC, and Financial Reporting Council will continually monitor the level of compliance with IAS 36 on disclosure of assets impairment. The aim of this is to ensure that assets value recorded is not more than the recoverable amount. Hence, this theory is equally relevant to this study.

\section{Review of Empirical Studies on performance}

Naceur (2003) asserted that the macro-economic indicators such inflation and growth rates have no impact on bank's interest margins and profitability; bank's interest margins on bank loans which have a positive and significant impact. The size has mostly negative and significant coefficients on the net interest margins and bank profitability. In a similar study, Ton (2009) concluded that increasing the amount of labour at a store is associated with an increase in profitability through its impact on conformance quality but not its impact on service quality. In another study by Hoffmann (2011) using GMM system estimator technique and the study documented a negative link between the capital ratio and the profitability, which supports the notion that banks are operating over-cautiously and ignoring potentially profitable trading opportunities.

Moulton (2011) showed that bank expenditures and non-interest income had the highest impact on banks' profitability, while bank capital, expenditure as a share of assets and credit risk were inversely related to banks' profitability. Similarly, Tan and Floros (2012) identified that higher cost efficiency, lower volume of non-traditional activity, higher banking sector and stock market development tend to increase profitability of Chinese banks. Furthermore, Kebewar (2012) concluded that debt has no influence on profitability. In the view of Trujillo-Ponce (2013) concluded that, high bank profitability during those years were associated with a large percentage of loans in total assets, a high proportion of customer deposits, good efficiency, and a low credit risk. In addition, higher capital ratios also increase the bank's return, although this finding applies only when using return on assets (ROA) as the profitability measure.

Almumani (2013) identified that profitability of the Jordanian commercial banks is influence by operational efficiency. Other variables, such as liquidity, credit composition, credit risk, capital adequacy and the size of the bank did not show any statistical effect on profitability. In another comparative study Almanaseer (2014) concluded that financial crisis does not have significant impact on Islamic banks profitability. Favourable macro-economic conditions, bank size and equity capital are important factors in increasing Islamic banks' profitability. Whereas, Abdullah, Parvez and Ayreen (2014) asserted that the profitability of the Bangladesh banking sector is determined by bank size, higher cost efficiency, capitalization, higher concentration. Credit risk and return on assets have a negative relationship.

In the study of Riaz, Furqan and Siddique (2015) it was revealed that advertising has positive and significant impact on the profitability of private sector banks but not on return on equity of public sector banks, while Hooshyari and Moghanloo (2015) concluded that inflation, bank size, liquidity have significant impact on profitability of banks. Similarly, Cheruiyot (2016) discovered a positive relationship between asset quality and commercial banks profitability, and also established a positive correlation between profitability of a bank and its size. But Habib, Khan and Wazir (2016) revealed that there is significant but negative relationship between debt and profitability.

In a related study on the developing countries, El-Kassem (2017) concluded that lower loan loss provision translated into higher profitability, and that understanding the quality of assets is the heart to assessing the health of the banking industry as a whole, while Kadioglu, Telceken and 
Ocal (2017) found that there is a significant, negative relationship between non-performing loans and bank profitability which is measured by return on equity and return on asset. conversely, Nurdiansyah, and Manda (2018) concluded that the level of allowance for bad debt does not significantly affect the level of profitability as measured by the comparison of operating expenses to operating income.

Conclusively, Uwuigbe, Uwuigbe, and Oyewo (2015) opined that ratio of non-performing loans and bad debt have a significant negative effect on the performance of banks in Nigeria, on the other hand, the relationship between secured and unsecured loan ratio and bank's performance was not significant, while Aminu and Malami (2015) identified that profitability and assets base have positive relationship with accounting standard compliance in Nigerian banking sector.

\section{Review of Empirical Studies on non-performing loan}

Ahmed, Raiz and Muhammad (2012) discovered that loan loss provision affects the banking profitability in Pakistan and that banks advances and deposits played vital roles in the determination of banking profitability, while the relation of bank size is found to be insignificant but positive with profitability. In a related study by Kimathi (2014) asserted that there exists a negative relationship between loan loss provision and profitability, while positive relationship was established between profitability of deposit taking and size of the institution, loan intensity and quality of management, while in the contribution of Ahmad, Tahir, and Aziz (2014) it was concluded that the loan loss provision is an important factor affecting profitability of banks. The study also revealed that a well-established bank is supposed to be having less loan loss provision and higher profitability. Tarko (2015) idetified NPLs rate, lending interest rate and GDP growth rate had statistically significant effect on the level of return on assets.

However, Ozurumba (2016) concluded that return on asset had inverse relationship with non-performing loans and loan loss provision respectively, but positively related to loans and advances. The study also posited that, the effects of non-performing loans on commercial banks' performance are negative. Akter and Roy (2017) investigated the impacts of non-performing loan on profitability in banking sector of Dhaka stock exchange and it was concluded that nonperforming loan ratio has statistically significant negative impact on net profit margin of listed banks for the study periods. Kingu, Macha, and Gwahula (2018) found that occurrence of nonperforming loans is negatively associated with the level of profitability in commercial banks in Tanzania.

Furthermore, Idris (2014) concluded that there is a relationship between bank loan monitoring and loan performance and that the more effective and efficient the monitoring, the higher the loans will remain active. Javed and Khurshid (2016) revealed that debt have effect on the profitability of banks. In the contribution of Akinlo and Emmanuel (2014) the study concluded that in the long run, economic growth is negatively related to non-performing loan, and that credits to the private sector, exchange rate, lending rate and stock market index are the main determinants of non-performing loans. Buchory (2015) also asserted that non-performing loan ratio has positive and significant effect on return on assets, while the operational efficiency has negative and significant effects on the return on assets.

In addition Nyarko-Baasi (2018) revealed that non-performing loan ratio negatively affect profitability of banks. Likewise Ojo and Somoye (2013) discovered that nonperforming loans, commercial bank interest rate, liquidity ratio and inflation exert long-run relationship and significant influence on financial development. Adegbie and Dada (2018) asserted that nonperforming loans have significant negative impact on the assets. 


\section{Review of Empirical Studies on Impairment}

Lustosa, Rodrigues, and Goncalves (2008) concluded that discount rate as a parameter in a firm's valuation assessment is important for the write-off decision resulting from an impairment test and that firm's economic value is sensitive to the use of a sole growth rate to calculate the perpetuity considering that any changes in the rate will alter the decision based on the test. In another similar study Nethercott, and Anamourlis (2009) asserted that, the issue of the impairment of intangible assets on a regular periodic basis only applies where such assets qualify as depreciating assets for the purposes of income tax assessment Act. In other circumstances, any impairment only arises where there is a sale of the asset concerned even though impairment to the asset may have occurred at some earlier time. In the contribution of Atomei and Robu (2011) on methodological and programming impairment solution of performing loans for banking companies in Romania. It was concluded that impairment methodology is crucial in banking profitability, also the inputs in impairment solutions should acquire special attention.

Haddad, Al-Hare and Abu Ghazaleh (2012) examined the value relevance of goodwill impairments, United Kingdom evidence. Ordinary least squares regression model was employed for the analysis, and it was concluded that there is significant negative association between goodwill impairment loss and firm's value. However, Laghi, Mattei and Marcantonio (2013) assessed the value relevance of goodwill impairment considering country-specific factors in EU listed companies. The study used multivariate ordinary least square regression and the result revealed that there is a significant negative association between reported goodwill impairment losses and market values.

Sooriyakumaran and Velnampy (2013) concluded that impairment losses had a significant impact on reported profits, and impairment loss was a significant component of the reported overall loss. In another related study by Sooriyakumaran and Velnampy (2014) concluded that impairment of assets was found to have a negative and significant impact on profitability and capital structure.

According to the study of Miron and Burja (2015) has proved the existence of negative correlation between the impairments of assets and economic performance measured by profit before tax. Similarly, Abrigo and Ferrer (2015) studied the effect of management compensation and debt requirements on earnings management concerning the impairment of assets in Philippines. Regression analysis method was used for the analysis, and it was concluded that financially strong companies are deferring their impairment recognition to obtain a lower cost of financing.

Fernandes, Gonçalves, Guerreiro and Pereira (2016) researched on impairment losses: causes and impacts in Portugal. The study adopted fixed and random effect regression analysis and chi-square test for te analysis and the study posited that the amount of impairment losses showed an upward trend, and that these losses are most significant among intangibles, and that impairment losses had negative relationship to market value. Similarly Nawaiseh (2016) asserted that, leverage, return on assets and return on equity have negative and statistically insignificant relationship with impairment recognition.

In the study of Bussoli, Conca, Gigante and Madaro (2016) on determinants of impaired loans and doubtful loans in Italy. The incidence of banks' size, financial and macroeconomic indicators on the ratio of impaired loans to gross loans, and the ratio of doubtful loans to total asset were examined. Pooled ordinary least square regressions models were used for the analyses. The researchers argued that the ratio of impaired loans to gross loans and the ratio of doubtful loans to total asset were negatively related to return on average assets and to banks' size. Therefore, 
Olaleye, Agboola, Solomon and Oyerogba (2014 asserted that there is increase in the number of banks which disclosed impairment losses as well as the value of impairment losses.

\section{Gap Identified from Literature Reviewed}

Evidently, only few of the previous studies on assets impairment and profitability focused on risk assets impairment and profitability in the Nigerian banking sector. The related studies were carried out in foreign countries with culture, language, and legislation different from Nigeria. Therefore, findings from previous studies proved insufficient to gain insight into risk assets impairment, and its effect on profitability in Nigerian deposit money banks. The present study finds relevance in view of such gap in research.

\section{METHODOLOGY}

The study employed fixed and random effect regression panel model and correlational research design to determine the relationship between risk assets impairment and profitability in the Nigerian deposit money banks. The study used both descriptive and inferential analysis techniques for analysing the data collected. secondary data was used

\section{Study Population and Sample Size Determination}

The study population were all the twenty (22) deposit money banks in Nigeria, while the sample size comprised fourteen (14) deposit money banks in Nigeria and they were selected based on some criteria such as: (i) public quoted banks; and (ii) data available for the period (iii) banks that retained their brand names.

Therefore, the fourteen banks selected are; Eco Bank, Diamond Bank, First Bank PLC, United Bank of Africa (UBA), Guaranty Trust Bank (GTB), Union Bank, Unity Bank, First City Monument Bank (FCMB), Fidelity Bank, Access Bank, Sterling Bank, Wema Bank, Stanbic IBTC Bank, and Zenith Bank determine the

\section{Econometrics Models:}

$\mathrm{OPR}_{\text {it }}=\beta_{0} \alpha+\beta_{1} \mathrm{IL}_{\text {it }}+\beta_{2} \mathrm{NPLR}_{\text {it }}+\beta_{3} \mathrm{BS}_{\text {it }}+\beta_{4} \mathrm{INF}_{\text {it }}+\beta_{5} \mathrm{GDPGR}_{\text {it }}+\beta_{6} \mathrm{LIQ}_{\text {it }}+\mathcal{E}_{\text {it - (i) }}$

$\mathrm{ROA}_{\text {it }}=\beta_{0} \alpha+\beta_{1} \mathrm{IL}_{\text {it }}+\beta_{2} \mathrm{NPLR}_{\text {it }}+\beta_{3} \mathrm{BS}_{\text {it }}+\beta_{4} \mathrm{INF}_{\text {it }}+\beta_{5} \mathrm{GDPGR}_{\text {it }}+\beta_{6} \mathrm{LIQ}_{\text {it }}+\mathcal{E}_{\text {it - (ii) }}$

OPR: Operating profit before tax

ROA: Return on Assets

IL: Impairment loss

NPLR: Non-performing loan ratio

BS: Bank Size

INF: Inflation rate

GDPGR: Gross domestic product growth rate

LIQ: Liquidity risk

The contribution of each independent variable to the variation in the dependent variable was evaluated from the regression coefficients $\beta_{1}, \beta_{2}, \beta_{3}, \beta_{4}, \beta_{5}, \beta_{6}$ and $\varepsilon$ is the error term. 
Table 1. Variables measurement units \& a priori expectations

\begin{tabular}{|c|c|c|c|c|}
\hline $\begin{array}{cc}\text { Type } & \text { of } \\
\text { variable } & \end{array}$ & Variable & Indicator & Measurement & Apriori Expectation \\
\hline \multirow{6}{*}{$\begin{array}{l}\text { Independent } \\
\text { variable }\end{array}$} & $\begin{array}{l}\text { Impairment } \\
\text { loss }\end{array}$ & IL & $\begin{array}{l}\text { Impairment } \\
\text { charge for the } \\
\text { year }\end{array}$ & Negative relationship \\
\hline & $\begin{array}{l}\text { Non- } \\
\text { performing } \\
\text { loan ratio }\end{array}$ & NPLR & $\begin{array}{l}\text { Non-performing } \\
\text { loan / Total loan } \\
\text { advances }\end{array}$ & Negative relationship \\
\hline & Bank size & $\mathrm{BS}$ & $\begin{array}{l}\text { Natural } \\
\text { logarithm of the } \\
\text { bank's total } \\
\text { assets }\end{array}$ & positive \\
\hline & Inflation & INF & $\begin{array}{l}\text { Inflation rate of } \\
\text { the country }\end{array}$ & Positive/negative \\
\hline & $\begin{array}{l}\text { Gross } \\
\text { domestic } \\
\text { product } \\
\text { growth rate }\end{array}$ & GDPGR & $\begin{array}{l}\text { Year percentage } \\
\text { change of the } \\
\text { country GDP }\end{array}$ & positive \\
\hline & Liquidity risk & LIQ & $\begin{array}{l}\text { The ratio of total } \\
\text { loan / Total } \\
\text { Assets }\end{array}$ & negative \\
\hline & $\begin{array}{l}\text { Return on } \\
\text { Assets }\end{array}$ & $\mathrm{ROA}$ & $\begin{array}{l}\text { Net income after } \\
\text { Tax / total assets }\end{array}$ & \\
\hline & $\begin{array}{l}\text { Operating } \\
\text { profit before } \\
\text { tax }\end{array}$ & OPR & $\begin{array}{l}\text { Operating profit } \\
\text { before tax / Gross } \\
\text { Revenue }\end{array}$ & \\
\hline
\end{tabular}

Source: Authors' computation, 2019

\section{Definition of Variables}

\section{Return on Assets (ROA)}

ROA expresses the risk taking behaviour of bank management in obtaining the satisfied level of profit per unit of total resources. This study has used ROA as dependent variable to represent bank performance. ROA measures the profit earned per naira of assets and reflect how well bank management uses the bank's real investments resources to generate profits (Naceur, 2003 and Alkassim, 2005).

\section{Operating profit before tax}

Operating profit before tax is a measure of profitability. It indicates how much of each naira of revenues is left over after both costs of goods sold and operating expenses are considered (Pandey, 2007). 


\section{Impairment loss $(\mathrm{IL})$}

Impairment loss is the amount by which the carrying amount of an asset or cash-generating unit exceeds its recoverable amount. Carrying amount is the amount at which an asset is recognised in the balance sheet after deducting accumulated depreciation and accumulated impairment losses (IAS, 36).

\section{Non-performing loans (NPL)}

Non-performing loans (NPL) reflects the bank's credit quality and is considered as an indicator of credit risk management. NPL, in particular, indicates how banks manage their credit risk because it defines the proportion of loan losses amount in relation to total loan amount (Hosna et al, 2009). NPL has been used as the default rate on total loan and advances.

\section{Bank Size (BS)}

Natural logarithm of book value of total assets is used as a proxy to measure bank size and this proxy is able to capture the possible cost advantages related with the size (Sufian \& Chong, 2008). Bank size was found to have significant positive impact on commercial banks profitability by Naceur (2003), Kimathi (2014) and Almanaseer (2014).

\section{Inflation rate (INF)}

Inflation is the rate at which the general level of prices for goods and services is rising in the economy overtime. Inflation was found to have significant positive impact on commercial banks' profitability by Kutsienyo (2011), Hooshyari and Moghanloo (2015)

\section{GDP growth rate (GDPR)}

The gross domestic product growth is the annual change in the GDP. Tarko (2015) found that there is a positive association between economic growth and financial sector profitability.

\section{Liquidity risk (LIQ)}

Liquidity is the amount of short term responsibilities that could be met with the amount of liquid assets. It is proxy by ratio of total loan to total assets in line with the study of Molyneux and Thorton (1992) and Guru et al. (2002) found a negative relationship between liquidity and bank profitability, while Almazari (2014) found a positive relationship between liquidity and bank profitability.

\section{DATA ANALYSIS AND RESULT INTERPRETATION}

This chapter presents the research findings to show influence of risk assets impairment on profitability. The study was conducted on 14 deposit money banks in Nigeria where secondary data for the period of 2012 to 2017 was used. STATA data analysis software was employed in analysing data in order to establish the influence of risk assets impairment on profitability. The study used panel data, fixed and random regression method were employed.

\section{Data Analysis}

\section{Descriptive Statistic Summary}

The dependent variables used were return on assets, return on equity and operating profit used to measure profitability of the banks while explanatory variables were gross domestic product per capital, inflation rate, liquidity ratio, impairment loss, non-performing loan ratio and bank 
size(total assets). Table 2 reports mean, maximum, minimum, standard deviation and number of observations for each variables used in this study.

Table 2. Summary Statistics of Variables

\begin{tabular}{|c|c|c|c|c|c|}
\hline Variable. & Obs. & Mean. & Std. Dev. & Min & Max \\
\hline $\begin{array}{l}\text { Impairment } \\
\text { loss.(=N='million). }\end{array}$ & 84 & 20500 & 22800 & 77.64 & 126000 \\
\hline $\begin{array}{l}\text { Non-performing loan } \\
\text { ratio }\end{array}$ & 84 & 4.57 & 4.56 & 0 & 25.5 \\
\hline Return on equity. & 84 & 2.02 & 1.70 & -2.01 & 8.71 \\
\hline Return on assets & 84 & 8.37 & 45.61 & -394.31 & 56.7 \\
\hline Operatin profit & 84 & 16.34 & 12.23 & -16.08 & 51.68 \\
\hline $\begin{array}{l}\text { Gross domestic } \\
\operatorname{product}(\$)\end{array}$ & 84 & 5810.49 & 223.32 & 5385.88 & 6053.26 \\
\hline Inflation rate & 84 & 11.65 & 3.448293 & 8 & 16.5 \\
\hline $\begin{array}{l}\text { Total Assets('million } \\
\text { naira) }\end{array}$ & 84 & 1760 & 1210 & 246 & 5240 \\
\hline Liquidity ratio & 84 & 48.05 & 8.92 & 23.82 & 63.98 \\
\hline
\end{tabular}

Source: Author's Computation, 2019.

Table 2 shows the summary statistic of the variables of the models. These variables include impairment loss, non-performing ratio, return on assets, liquidity, bank size (total assets), operating profit, return on equity, inflation, and gross domestic product.

Impairment loss averaged 20.5 billion naira with standard deviation of about 2.28 billion naira, while the firm with the lowest impairment loss during the period had 77.640 million naira and the bank with the highest impairment loss during the period has 12.6 billion naira.The result presented in Table 2 also shows that on the average, a bank liquidity selected randomly is about 48 percent. This has a standard deviation of about 8.95 percent, while a bank with minimum liquidity had 23.82 percent during the period observed, a bank with maximum liquidity had 63.98 percent during this period. As to the country' statistics regarding their inflation rate, average inflation rate that affected this sample is about 11.65 percent with average spread of 3.44 . The lowest inflation rate during the period under study is 8 percent while the highest inflation rate during this period is about 16.50 percent. The country's gross domestic product per capital averaged about $\$ 5810.491$ over the period under consideration with standard deviation of about $\$ 223.322$. The country has as low as $\$ 5385.88$ gross domestic product per capital during the period while annual gross domestic product per capital was as high as about $\$ 6053.26$.

As regard to the level of bank size (measured in total assets), an average bank in the sample is as big as about 1.76 trillion Naira, having a sample spread of about 1.21 trillion Naira, while a bank at a point have as low as 2.46 billion Naira as total assets, a bank has as high as 5.24 trillion Naira as total assets. Return on equity averaged about 2.02 with standard deviation of about 1.7. The bank with the lowest return on equity during the period under study was -2.01 while the bank with the highest level of return on equity had about 8.71. Return on assets averaged about 8.37 with standard deviation of about 45.6. The bank with the lowest return on assets during the period under study was -394.31 while the bank with the highest level of return on assets has about 56.7. 
On the average, banks in this sample have operating profit of 16.34 percent and standard deviation of 12.23. While banks have as low as -16.08 percent operating profit, banks have as high as 51.68 operating profit.

\section{Correlation Analysis}

Correlation analysis was carried out to examine multicollinearity effect among explanatory variables.

Table 3. Correlation analysis among independent variables

\begin{tabular}{|c|c|c|c|c|c|c|c|c|c|}
\hline & ROE & ROA & OPR & INFL & LIQ & $\mathrm{BS}$ & IL & GDPR & NPLR \\
\hline ROE & 1 & & & & & & & & \\
\hline ROA & 0.4098 & 1 & & & & & & & \\
\hline OPR & 0.418 & 0.7651 & 1 & & & & & & \\
\hline INFL & $\begin{array}{l}- \\
0.0297\end{array}$ & 0.0099 & -0.1025 & 1 & & & & & \\
\hline LIQ & 0.1864 & 0.0156 & -0.0115 & 0.0966 & 1 & & & & \\
\hline BS & 0.2987 & 0.3186 & 0.4789 & 0.1188 & 0.1441 & 1 & & & \\
\hline IL & 0.0753 & 0.039 & -0.0271 & 0.2462 & 0.2654 & 0.5097 & 1 & & \\
\hline GDPR & 0.1744 & $\begin{array}{l}- \\
0.0414\end{array}$ & -0.0319 & -0.1167 & 0.2037 & 0.1436 & $\begin{array}{l}0.244 \\
4\end{array}$ & 1 & \\
\hline \begin{tabular}{|l|} 
NPLR \\
\end{tabular} & $\begin{array}{l}- \\
0.2328\end{array}$ & $\begin{array}{l}- \\
0.1309\end{array}$ & -0.381 & 0.171 & -0.0562 & -0.3625 & $\begin{array}{l}0.236 \\
6\end{array}$ & 0.0662 & 1 \\
\hline
\end{tabular}

Source: Author's Computation, 2019.

The correlation results in table 3 showed that none of the variables have multicollinearity issue since the highest correlation results among the explanatory variables was 0.5 which is lesser than 0.8 . The correlation results showed no evidence of multicollinearity using these variables in the models.

\section{Inferential Analysis}

To establish the influence of risk assets impairment on performance of Nigerian listed deposit money banks, a panel fixed, and random effects models was conducted with heteroskedasticityrobust estimates of standard errors. The results for all the models are presented in tables 4 and 5 . 
Table 4. Regression Results of impairment loss's effect on operating profit.

\begin{tabular}{|c|c|c|c|c|c|c|c|c|c|}
\hline & \multicolumn{3}{|c|}{-1} & \multicolumn{3}{|c|}{-2} & \multicolumn{3}{|l|}{-3} \\
\hline VARIABLES & Fixed & Effects & & Random & effects & & $\begin{array}{c}\mathrm{AR}(1) \\
\text { Random }\end{array}$ & Effects & \\
\hline & $\begin{array}{l}\text { Coeffi } \\
\text { cient }\end{array}$ & $\begin{array}{l}\text { Std. } \\
\text { Err. }\end{array}$ & $\begin{array}{l}\text { P.valu } \\
\text { e }\end{array}$ & $\begin{array}{l}\text { Coeffici } \\
\text { ent }\end{array}$ & Std. Err. & P.value & Coefficient & $\begin{array}{l}\text { Std. } \\
\text { Err. }\end{array}$ & $\begin{array}{l}\mathrm{P} \\
\text { value }\end{array}$ \\
\hline NPLR & -0.084 & -0.213 & 0.694 & -0.099 & -0.207 & 0.632 & -0.129 & -0.191 & 0.499 \\
\hline INFL & $\begin{array}{l}- \\
0.591 \\
* *\end{array}$ & -0.283 & 0.041 & $-0.481 * *$ & -0.235 & 0.040 & -0.332 & -0.258 & 0.198 \\
\hline LIQ & 0.032 & -0.115 & 0.778 & 0.0145 & -0.108 & 0.892 & -0.0043 & -0.11 & 0.969 \\
\hline $\mathrm{BS}$ & $\begin{array}{l}14.05 \\
1 * *\end{array}$ & -5.617 & 0.015 & $\begin{array}{l}11.22 * * \\
*\end{array}$ & -3.264 & 0.001 & $12.03 * * *$ & -2.901 & 0.000 \\
\hline GDPR & $\begin{array}{l}- \\
39.85 \\
1 \\
\end{array}$ & -26.83 & 0.142 & -28.8 & -21.51 & 0.181 & -22.92 & -23.24 & 0.324 \\
\hline $\mathrm{IL}$ & $\begin{array}{l}- \\
1.675 \\
*\end{array}$ & -0.916 & 0.072 & $-1.828 * *$ & -0.864 & 0.034 & $-2.294 * * *$ & -0.809 & 0.005 \\
\hline Constant & $\begin{array}{l}98.84 \\
1 \\
\end{array}$ & -175.6 & 0.575 & 64.71 & -166.2 & 0.697 & 3.556 & -186.9 & 0.985 \\
\hline Obs & 84 & & & 84 & & & 84 & & \\
\hline R-sq & 0.197 & & & & & & & & \\
\hline No. of panelid & 14 & & & 14 & & & 14 & & \\
\hline F/Wald Chi2 & $\begin{array}{c}2.62 * \\
*\end{array}$ & & 0.024 & $\begin{array}{c}22.02 * * \\
*\end{array}$ & & 0.012 & $27.86 * * *$ & & 0.000 \\
\hline $\begin{array}{l}\text { F-test of } \\
\text { Homogeneity }\end{array}$ & $\begin{array}{c}11.73 \\
* * *\end{array}$ & & 0.000 & & & & & & \\
\hline Hausman Test & 0.59 & & 0.996 & & & & & & \\
\hline $\begin{array}{l}\text { Wooldridge AR } \\
\text { Test }\end{array}$ & $\begin{array}{l}20.83 \\
* * *\end{array}$ & & 0.000 & & & & & & \\
\hline
\end{tabular}

Source: Author's Computation, 2019.

The fixed and random effects model results presented in Table 4 shows the effect of impairment loss on operating profit. The standard F-test of homogeneity conducted to determine if the OLS method (see appendix) is applicable is also presented in the Table 4. The test shows a statistic value of 11.73 and p-value of 0.000 which indicates that the statistic is significant. The significance of this statistic is also suggestive of the fact that the OLS method is not applicable in this case since the null hypothesis of homogeneity among panel members is rejected. This implies that models that capture heterogeneous panel such as the fixed and random effects are also required in this case. Hausman test was also presented in Table 4 to make appropriate choice between the fixed and random effects models. The Hausman test shows a Chi-squared value of 0.59 and p- 
value of 0.99 indicating that the statistic is not significant. This indicates that the null hypothesis that the difference in both model is not systematic is not rejected. This implies that the random effects model is more appropriate in this case.

The result of random effects model exhibit first-order autocorrelation. This is evident from the Wooldridge test of first-order autocorrelation which shows a value of 20.8 and p-value of 0.000 indicating it is statistically significant. Its significance implies rejection of null hypothesis of no first-order autocorrelation, hence, there is presence of autocorrelation in the model. This prompted an estimation of the model based on the autocorrelation-corrected random effects which accommodates first-order serially correlated disturbances.

The AR(1) random effects model shows that bank size, and impairment loss have statistically significant impact on operating profit while inflation, liquidity, gross domestic product, and non-performing loan do not have statistically significant impact on operating profit. Impairment loss and bank size are statistically significant at 0.01 levels. This implies that impairment loss and bank size are important determinants of operating profit. On the other hand, proportion of inflation, liquidity, gross domestic product and non-performing loan for the accounting year do not determine the level of operating profit.

Some of the factors in this model i.e. inflation, liquidity, gross domestic product, nonperforming loan and impairment loss have negative coefficients, indicating that they influence operating profit negatively, while bank size have positive influence on operating profit.

The positive coefficient of bank size indicates that a percent increase in the bank size (deposit) will result to a rise in operating profit by about 0.120 percent point, and vice versa. Similarly, a naira increase in impairment loss will lead to a fall in operating profit by about 0.022 percent point, and vice versa. Also, an increase in gross domestic product will result to decrease in operating profit by about 0.229 percent points, and vice versa. In the same vein, a percent increase in inflation rate will reduce operating profit by 0.33 percent, and vice versa. A percent increase in liquidity ratio will result to a decrease in operating profit by about 0.0042 percent, and vice versa.

The Wald Chi-squared statistic presented for the AR (1) random effects model shows a value of 27.96 and p-value of 0.000 which indicates statistical significance of the model. This implies that the overall model is statistically significant at 1 percent level of significance. Rsquared shows a value of 0.197 , indicating that 19.7 percent of variations in the operating profit is explained in the model.

Table 5. Regression Results of effect of Non-performing loan on return on assets.

\begin{tabular}{|l|l|l|l|l|l|l|l|l|l|}
\hline & \multicolumn{3}{|c|}{-1} & \multicolumn{3}{c|}{-2} & \multicolumn{2}{l|}{-3} \\
\hline $\begin{array}{l}\text { VARIA } \\
\text { BLES }\end{array}$ & Fixed & \multicolumn{2}{|l|}{ Effects } & \multicolumn{2}{l|}{$\begin{array}{l}\text { AR(1) } \\
\text { Random } \text { Effects }\end{array}$} \\
\hline & Coef. & $\begin{array}{l}\text { Std. } \\
\text { Err. }\end{array}$ & $\begin{array}{l}\text { P.va } \\
\text { lue }\end{array}$ & Coef & $\begin{array}{l}\text { Std. } \\
\text { Err. }\end{array}$ & $\begin{array}{l}\text { P.va } \\
\text { lue }\end{array}$ & Coef & Std. Err. & Pvalue \\
\hline NPLR & $0.078^{*}$ & -0.042 & $\begin{array}{l}0.06 \\
7\end{array}$ & $0.072^{*}$ & -0.040 & $\begin{array}{l}0.07 \\
7\end{array}$ & $0.067 *$ & -0.037 & 0.070 \\
\hline INFL & -0.027 & -0.056 & $\begin{array}{l}0.63 \\
0\end{array}$ & -0.019 & -0.044 & $\begin{array}{l}0.66 \\
6\end{array}$ & -0.019 & -0.050 & 0.697 \\
\hline LIQ & -0.003 & -0.022 & $\begin{array}{l}0.87 \\
0\end{array}$ & -0.002 & -0.020 & $\begin{array}{l}0.91 \\
2\end{array}$ & -0.002 & -0.021 & 0.896 \\
\hline
\end{tabular}




\begin{tabular}{|c|c|c|c|c|c|c|c|c|c|}
\hline $\mathrm{BS}$ & 1.503 & -1.115 & $\begin{array}{l}0.18 \\
2\end{array}$ & $1.260 * *$ & -0.513 & $\begin{array}{l}0.01 \\
4\end{array}$ & $\begin{array}{l}1.304 * * \\
*\end{array}$ & -0.481 & 0.007 \\
\hline GDPR & -4.108 & -5.328 & $\begin{array}{l}0.44 \\
4\end{array}$ & -3.406 & -4.033 & $\begin{array}{l}0.39 \\
8\end{array}$ & -2.447 & -4.54 & 0.590 \\
\hline IL & -0.182 & -0.182 & $\begin{array}{l}0.13 \\
1\end{array}$ & $-0.275^{*}$ & -0.167 & $\begin{array}{l}0.09 \\
9\end{array}$ & $-0.260 *$ & -0.156 & 0.096 \\
\hline $\begin{array}{l}\text { Constan } \\
\mathrm{t}\end{array}$ & 10.62 & 9.49 & $\begin{array}{l}0.76 \\
2\end{array}$ & 9.49 & -32.57 & $\begin{array}{l}0.77 \\
1\end{array}$ & 0.0915 & -37.44 & 0.998 \\
\hline Obs & 84 & & & 84 & & & 84 & & \\
\hline R-sq & 0.082 & & & & & & & & \\
\hline $\begin{array}{l}\text { No. of } \\
\text { panelid }\end{array}$ & & 14 & & 14 & & & 14 & & \\
\hline $\begin{array}{l}\text { F/Wald } \\
\text { Chi2 }\end{array}$ & 0.95 & & $\begin{array}{l}0.46 \\
7\end{array}$ & 7.74 & & $\begin{array}{l}0.25 \\
7\end{array}$ & 8.87 & & 0.261 \\
\hline $\begin{array}{l}\text { F-test of } \\
\text { Homog } \\
\text { eneity }\end{array}$ & $\begin{array}{l}5.98 * * \\
*\end{array}$ & & $\begin{array}{l}0.00 \\
0\end{array}$ & & & & & & \\
\hline $\begin{array}{l}\text { Hausma } \\
\text { n Test }\end{array}$ & 0.51 & & $\begin{array}{l}0.99 \\
7 \\
\end{array}$ & & & & & & \\
\hline $\begin{array}{l}\text { Wooldri } \\
\text { dge AR } \\
\text { Test }\end{array}$ & $\begin{array}{l}7.52 * * \\
*\end{array}$ & & $\begin{array}{l}0.01 \\
6\end{array}$ & & & & & & \\
\hline
\end{tabular}

Source: Author's Computation, 2019.

The fixed and random effects model results presented in Table 5 shows the effect of nonperforming loans on return on assets. The standard F-test of homogeneity conducted to determine if the OLS method (see appendix) is applicable is also presented in the Table 5. The test shows a statistic value of 5.98 and p-value of 0.000 which indicates that the statistic is significant. The significance of this statistic is also suggestive of the fact that the OLS method is not applicable in this case since the null hypothesis of homogeneity among panel members is rejected. This implies that models that capture heterogeneous panel such as the fixed and random effects are also required in this case. Hausman test was also presented in Table 5 to make appropriate choice between the fixed and random effects models. The Hausman test shows a Chi-squared value of 0.51 and pvalue of 0.99 indicating that the statistic is not significant. This indicates that the null hypothesis that the difference in both model is not systematic is not rejected. This implies that the random effects model is more appropriate in this case.

The result of random effects model exhibit, first-order autocorrelation. This is evident from the Wooldridge test of first-order autocorrelation which shows a value of 7.52 and p-value of 0.016 indicating it is statistically significant. Its significance implies rejection of null hypothesis of no first-order autocorrelation, hence, there is presence of autocorrelation in the model. This prompted an estimation of the model based on the autocorrelation-corrected random effects which accommodates first-order serially correlated disturbances. 
The AR (1) random effects model shows that bank size, non-performing loan and impairment loss have statistically significant impact on return on assets while inflation, liquidity, and gross domestic product do not have statistically significant impact on return on assets. Bank size is statistically significant at 0.01 levels, while Impairment loss and non-performing loan are statistically significant at 0.1 levels. This implies that impairment loss, non-performing loan and bank size are important determinants of return on assets. On the other hand, proportion of inflation, liquidity, and gross domestic product for the accounting year do not determine the level of return on assets.

Some of the factors in this model i.e. inflation, liquidity, gross domestic product, and impairment loss have negative coefficients, indicating that they influence return on assets negatively, while bank size and non-performing loan have positive influence on return on assets.

The positive coefficient of bank size indicates that a percent increase in the bank size will result to a rise in return on assets by about 0.013 percent point, and vice versa. Similarly, a percent increase in non-performing loan will lead to a rise in return on assets by about 0.068 percent, and vice versa. Also, an increase in gross domestic product will result to decrease in return on assets by about 0.024 percent points, and vice versa. In the same vein, a unit increase in inflation rate will reduce return on assets by 0.019 naira, and vice versa. A unit increase in liquidity ratio will result to a decrease in return on assets by about 0.0027 naira, and vice versa. Finally, a percent increase in impairment loss will lead to a reduction in return on assets by about 0.003 percent point, and vice versa.

The Wald Chi-squared statistic presented for the AR (1) random effects model shows a value of 8.87 and p-value of 0.26 which indicates statistical insignificance of the model. This implies that the overall model is statistically insignificant at all level of significance. R-squared shows a value of 0.082 , indicating that 8.2 percent of variations in the return on assets is explained in the model.

\section{Statement and Test of Hypotheses}

This part considers the two null hypotheses formulated with a view to either accepting or reject them, using fixed and random effect regression analysis method and the result is based on autocorrelation-corrected random effect models.

\section{Hypothesis One}

This hypothesis states that impairment loss does not have significant effect on operating profit. The hypothesis was tested with the use of random effect regression method. The result of the analysis are presented in Table 4 . The result indicated that there is significant statistical influence of impairment loss on operating profit ( $\mathrm{P}$ value is $0.005, \mathrm{p}<0.05)$. This finding suggests that impairment loss influences operating profit. Therefore, the null hypothesis is not accepted, while the alternate hypothesis is accepted.

\section{Hypothesis Two}

This hypothesis states that non-performing loan does not have significant effect on return on assets. The hypothesis was tested with the use of random effect regression method. The result of the analysis are presented in Table 5. The result indicated that there is statistically significant influence of non-performing loan on return on assets ( $\mathrm{P}$ value is $0.070, \mathrm{p}<0.1)$. This finding suggests that non-performing loan have significant influence on return on assets. Therefore, the null hypothesis is not accepted, while the alternate hypothesis is accepted. 


\section{Discussion of Findings}

The findings of this study show that keeping all other factors constant, an increase in nonperforming loan will lead to 0.0675 increase in Nigerian deposit money banks' profitability measured by return on assets vice versa. Also an increase in impairment loss will lead to 2.294 decrease in Nigerian deposit money banks' profitability measured by operating profit, while an increase in bank size will leads to 34.16 increase in Nigerian deposit money bank profitability measured by return on equity. This agrees with submission of Ahmed, Raiz and Muhammad (2012); Bussoli, Conca, Gigante and Madaro (2016) that return on asset have an inverse relationship with loan loss provision. This finding is contrary to the study of Ozurumba (2016) who concluded that return on assets and return on equity have inverse relationship with loan loss provision.

Objective one is on influence of impairment loss on profitability. The result obtained showed that impairment loss has negative significant influence on profitability. This finding is in support of Sooriyakumaran and Velnampy (2014) which affirmed that impairment of assets was found to have a negative and sigmificant impact on profitability. Haddad, Al-Hare, and AbuGhazaleh (2012; Ahmad, Tahir, and Aziz (2014); Miron and Burja (2015); El-Kassem (2017) who concluded that loan loss provisioning has negative effect on operating profit. This could be explained by the position of agency theory by Jenson and Meckling (1976) who proposed that the managers are more interested in profitability and then employ all tactic to reduce risk assets impairment to improve reported profit.

Objective two is on the influence of non-performing loan on return on assets. The result showed that non-performing loan have significant negative influence on return on assets. This is in agreement with Ahmed, Raiz and Muhammad (2012); Bussoli, Conca, Gigante and Madaro (2016) who found return on asset to have inverse relationship with loan loss provision. This could be explained by legitimacy theory that is aimed at ensuring that assets is reported at not more than the recoverable value, hence regulatory authority keeps close supervision on banks to ensure this is achieved.

The findings of the study using operating profit to measure profitability holding all other dependent variables constant also showed that impairment loss have significant negative effect on operating profit and Bank Size have significant positive influence on profitability, while inflation, liquidity, non-performing loan and gross domestic product rate have negative insignificant influence on profitability. This is in agreement with Ahmed, Raiz and Muhammad (2012) who found the relation between bank size and profitability to be insignificant but positive and Naceur (2003) that inflation and growth rates have no impact on bank's interest margins and profitability. This is contrary to the findings of Naceur (2003) that size has mostly negative and significant coefficients on bank profitability; Hooshyari and Moghanloo (2015) concluded that inflation has significant impact on profitability of banks.

The findings of the study using return on assets to measure profitability holding all other independent variables constant also showed that Bank Size and non-performing loan ratio have significant positive influence on profitability, while inflation, gross domestic product rate, and liquidity, have negative insignificant influence on profitability. This is in agreement with Kimathi (2014) who found a positive relationship between size and profitability of deposit taking banks; Okoye, Evbuomwan, Achugamonu and Araghan (2014) found liquidity to have significant negative impact on return on assets. This is contrary to the findings of Ebenezer, Omar and Kamil (2017) who concluded that liquidity had a positive and significant effect on bank profitability; 
Nawaiseh (2016) confirmed insignificant statistical positive relationship between liquidity and profitability measured by (ROA).

\section{SUMMARY, CONCLUSION AND RECOMMENDATIONS}

\section{Summary}

The study examined the influence of risk assets impairment on profitability in Nigerian deposit money banks. The focus was to determine whether risk assets impairment influence profitability of Nigerian deposit taking money banks. In order to achieve the objectives, the study collected and analysed the relevant data for licensed Nigerian deposit money banks for six years from 2012 to 2017. Secondary data were collected from the regulators and annual financial statements of the banks to achieve the stated objective. Fixed-effect and random-effect regression analysis method were used to analyse the data from a sample of 14 Nigerian deposit money banks.

The study revealed that risk assets impairment have significant negative relationship with profitability at $0.01 \%$ and $0.1 \%$ level of significance with p-value of 0.005 and 0.096 when (measure with operating profit, and return on assets), while other factors like bank size, liquidity, non-performing loan, inflation and gross domestic product per capital also contributed to change in profitability. The study also found that there was negative relationship between profitability (measured with return on assets and operating profit) of deposit money banks and inflation, gross domestic product per capital, and liquidity. Bank size have positive and significant relationship with profitability. But non-performing loan have positive relationship with profitability (measured with return on equity and return on assets, but negative relationship with operating profit.

This shows that there was negative relationship between profitability of Nigerian deposit money banks and inflation, liquidity and gross domestic product. The study also revealed that there was negative relationship between profitability when measured with ROA and OPR of Nigerian deposit money banks and risk assets impairment. The study revealed that risk assets impairment, and bank size have significant influence on the profitability of Nigerian deposit money banks.

\section{Conclusion}

From the analysis of the data collected and interpretation of results, the study concluded that risk assets impairment has significant influence on profitability of the Nigerian deposit money banks. The study also concluded that inflation, liquidity and gross domestic product have negative impact on profitability, while bank size has positive impact on profitability.

From the study it was discovered that, bank size has significant positive effect on return on assets, which simply means that banks performance will be better when aggressive step is taking towards deposit mobilization for size expansion. For Nigerian banks to achieve sound financial system to avert possible future collapse of any other bank, impairment loss and non-performing loans needs to be reduced drastically by ensuring that borrower's collateral is on perfected mortgage not on equity mortgage as practiced by some of the banks, while single obligor limit of borrowers and the debt service ratio are adhered to.

In the case of non-performing loan, Nigerian deposit money banks have been discovered to be accruing income on non-performing loan, which can be termed as not compliant with prudential guideline. Therefore, such profit can be termed as tainted profit usually called windowdressing. 


\section{REFERENCES}

Abdullah M., Parvez, K., \& Ayreen, S. (2014). Bank specific, industry specific and macroeconomic determinants of commercial bank profitability: a case of Bangladesh. World Journal of Social Sciences 4(3). October 2014 Issue. Pp. 82 - 96.

Aboh, J. (2011). The Banking Sector Reforms and the Nigerian Economy: Pain and Gain of the Private Sector. A Lecture Delivered at the Private Sector Lecture Series of the Faculty of Management Sciences, Benue State University, Makurdi.

Abrigo, L., \& Ferrer, R. (2015). The effect of management compensation and debt requirements on earnings management concerning the impairment of assets in Philippines. Retrieved from DOI: 10.18196/jai.2016.0041.1-21.

Adegbie, F. F., \& Dada, O. T. (2018). Risk assets management, liquidity management and sustainable performance in Nigeria deposit money banks. International Journal of Accounting Research, 6(2). Retrieved from doi:10.4172/2472-114x.1000178

Ahmed, R. M., Raiz, H. A., \& Muhammad, U. Y. (2012). Does the loan loss provision affect the banking profitability in case of Pakistan; Asian Economic and Financial review 2(7):772783.Retrieved from http://www.conscientiabeam.com/eco

Ahmad, F. \& Tahir, S. H., \& Aziz, B. (2014). Impact of loan loss provision on bank profitability in Pakistan; Research Journal of Social Science \& Management, 3(12). Retrieved from https://researchgate.net/publication

Akinlo O., \& Emmanuel M. (2014). Determinants of non-performing loans in Nigeria. Journal of Accounting \& Taxation, 6(2), 2014, pp. 21-28

Akter, R., \& Roy, J. K. (2017). The impacts of non-performing loan on profitability: an empirical study on banking sector of Dhaka stock exchange. International Journal of Economics and Finance; 9(3); 2017 ISSN 1916-971X E-ISSN 1916-9728 Published by Canadian Center of Science and Education

Alkassim, F. A. (2005). The Profitability of Islamic and Conventional Banking in GCC Countries: A comparative study, University of Wales Bangor, United Kingdom.

Almazari, A. (2014). Impact of internal factors on bank profitability: comparative study between Saudi Arabia and Jordan. Journal of Applied Finance \& Banking, 4(1) Science press Ltd, 2014

Almanaseer, M. (2014). The impact of the financial crisis on the Islamic banks profitability evidence from Golf Corporation Council. International Journal of Financial Research $5(3) ; 2014$

Almumani, M. (2013). Impact of managerial factors on commercial bank profitability: empirical evidence from Jordan. International Journal of Academic Research in Accounting, Finance and Management Sciences 3(3), pp. 298-310

Amiraslani, H., Latridis, G. E., \& Pope, P. F. (2013). Accounting for Asset Impairment: A test for IFRS Compliance in Europe. A Research Report by the centre for financial analysis and reporting research; Cass Business School.

Aminu, A. \& Malami, M. (2015). Impact of bank compliance with accounting standards on profitability, asset base and number of branches in Nigeria. Studies in Humanities. Studies in Humanities, $8 . \quad$ Retrieved from https://www.researchgate.net/publication/320466938

Atomei, A., \& Robu, V. (2011). Methodological and programming impairment solution of performing loans for banking companies in Romania. International Conference on Economics and Finance Research IPEDR, 4 (2011) 
Bussoli, C., Conca, L., Gigante, M., \& Madaro, G. (2016). Determinants of impaired loans and doubtful loans in Italy. Journal of Business and Economics, 7(8), pp. 1215-1225. Retrieved from http://www.academicstar.us

Buchory, H. A. (2015). Effect of credit risk and operational efficiency on banking profitability. Journal of Business and Management Sciences, 3(4); (2015): 118-123. doi: 10.12691/jbms-3-4-3

CBN/NDIC (1995) Distress in the Nigerian Financial Service Industry: A CBN/NDIC collaborative study: Page publisher services ltd, Lagos, Nigeria.

CBN (2010). Prudential guidelines for deposit money banks in Nigeria. Retrieved from https://www.cbn.gov.ng/2014/ccd35

Christian, L., \& Christian L. (2009). Did fair-value accounting contributed to the financial crises? .Retrieved from; https://www.cfapubs.org/doi/full/10.2469/dig.v40.n2.29).

Cheruiyot, R. (2016). The effect of asset quality on profitability of commercial banks in Kenya

Codjia, M. (2017). How does an impairment loss affect the income statement? Bizfluent. Retrieved from https://bizfluent.com/info-12016658-impairment-loss-affect-incomestatement.html.

Davis, J. H., Schoorman, F., \& Donaldson, L. (1997). Toward a stewardship theory of management, Academy of Management Review, 22(1), pp. 20-47

Deegan, C., \& Unerman, J. (2006). Financial accounting theory, McGraw-Hill education, Maidenhead, Berkshire.

Ebenezer, O. O., Omar, W. A., \& Kamil, S. (2017). Bank specific and macroeconomic determinants of commercial bank profitability: empirical evidence from Nigeria. Journal of Finance \& Banking Studies 6(1), 2017:25-38. Retrieved from; https://doi.org/10.20525/ijfbs.v6i1.627

Ernst \& Young (2012). The new impairment model US financial institutions weigh in on the new impairment model being developed by the FASB and IASB February 2012.

El-Kassem, R. C. (2017). Determinants of banks' profitability: panel data from Qatar. Open Journal of Accounting, 6, 103-111. https://doi.org/10.4236/ojacct.2017.64009

Fernandes, S. A., Gonçalves, C., Guerreiro, C., \& Pereira, L. N., (2016). Impairment losses: causes and impacts. Journal of Business Management. São Paulo, 18(60), p. 305-318, Apr. /Jun. 2016.

Guru, B. J, Staunton \& Balashanmugam (2002). Determinants of commercial bank profitability in Malaysia. University Multimedia working papers, pp. $19-27$

Habib, H., Khan, F., \& Wazir, M. (2016). Impact of debt on profitability of firms; evidence from non-financial sector of Pakistan. City University Research Journal 6(1); January 2016 PP $70-80$

Haddad, A., Al-Hare, O., \& AbuGhazaleh, N. (2012). The value relevance of goodwill impairments: UK evidence. International Journal of Economics and Finance 4(4); April 2012. Retrieved from www.ccsenet.org/ijef

Hami, A., George, E. I., \& Peter, F. P. (2013). Accounting for asset impairment: a test for IFRS compliance across Europe. Retrieved from https://www.cass.city.ac.uk/pdf_file.

Hoffmann, P.S., (2011). Determinants of the profitability of the US banking industry. International Journal of Business and Social Science, 2(22); December 2011

Hosna, A., Manzura, B., and Juanjuan, S. (2009). 'Credit risk management and profitability in commercial banks in Sweeden. School of Business Economics and Law 
Hooshyari, N. \& Moghanloo, A.P (2015). Evaluating the impact of inflation on profitability of banks in Iran. Kuwait Chapter of Arabian Journal of Business and Management Review $4(9) ; 2015$.

IAS 36, N. (2009). "International Accounting Standard 36 Impairment of Assets". Practical Issues, which discusses practical issues in applying IAS 36. Retrieved from https://www.ey.com/ifrs

Idris, I. J., (2014). Bank loan monitoring and loan performance: study of deposit money banks in Nigeria. A Thesis Submitted to The School of Postgraduate Studies, Ahmadu Bello University Zaria. Retrieved from http://Kubanni.abu.edu/jspui/bitstream.

Javed, A., \& Khurshid, M. (2016). A review of impact of high debt on the profitability of the banks in Pakistan. Research Journal of Finance and Accounting 7(11), 2016.

Jensen, M.C., \& Meckling,W.H. (1976). Theory of the firm: managerial behaviour, agency costs and ownership structure. Journal of Financial Economics, 3(4), pp. 305-360

Kadioglu, E., Telceken, N., \& Ocal, N. (2017). Effect of the asset quality on the bank profitability in Turkey. International Journal of Economics and Finance; 9(7); 2017

Kebewar, M. (2012). The effect of debt on corporate profitability evidence from French service sector.

Kimathi, G. J. (2014). The effect of loan loss provisioning on profitability of deposit taking sacco societies in Nairobi country. A research project submitted in partial fulfilment of the requirement for the award of the degree of Master of Business Administration, school of business, university of Nairobi. Retieved from http://Erepository.uonbi.ac.ke/handle/gitonga21

Kingu, P., Macha, S., \& Gwahula, R. (2018). Impact of non-performing loans on bank's profitability: empirical evidence from commercial banks in Tanzania. International Journal of Scientific Research and Management (IJSRM). 6(1), 2018. Retrieved from: www.ijsrm.in ISSN (e): 2321-3418

KPMG (2007). Loan Impairment Modeling according to IAS 39 using Based II parameters. Retrieved from https://www.spi-romania.eu/programm2007/ifrs

Kutsienyo, L. (2011). The determinant of profitability of banks in Ghana. A thesis submitted to the institute of distance learning, Kwame Nkrumah University of Science and Technology

Laghi, E., Mattei, M., \& Marcantonio, M. (2013). Assessing the value relevance of goodwill impairment considering country-specific factors: evidence from EU listed companies. International Journal of Economics and Finance; 5(7); 2013. Retrieved from doi:10.5539/ijef.v5n7p32

Lustosa, P. R. B., Rodrigues, F. F., \& Gonçalves, R. S. (2008). Intangible assets impairment test issues: the case of a Brazilian telecommunications company.

Marz, M. (2018). Asset impairment on a financial statement" small business-Chron.com, http://smallbusiness.chron.com/asset-impairment-financial-statement-80858.html. Accessed 16 July 2018.

Methodology and solution implementation - practical experience; Deloitte. Retrieved from https://www.spi-romania.eu/programm2007/ifrs19

Miron, V. \& Burja, V. (2015). The reversible impairment of assets and the impact on economic performance in energy sector of Romania. Annals of the Constantin Brâncuşi” University of Târgu Jiu, Economy Series, 2(1), 2015

Molyneux, P. \& Thornton, J. (1992). Determinants of European banks profitability: a note. Journal of Banking and Finance, 16: 1173-1178. 
Moulton, A. (2011). An investigation of the determinants \& forecast performance of bank profits in Jamaican Banks. Financial Stability Department Research and Economic Programming Division Bank of Jamaica

Murcia, A. \& Kohlscheen, E. (2016). Moving in tandem: bank provisioning in emerging market economies. Monetary and Economic Department, BIS Working Papers No 548

Naceur, S. B. (2003). The determinants of the Tunisian banking industry profitability: panel evidence. Universite Libre de Tunis Working Papers.

Natalia, C., Adam, K. \& Brcharest (2007). Impairment and provisioning Under IFRS.

Nawaiseh, M.E. (2016). Can impairment recognition under IAS 36 be improved by financial performance?. International Journal of Economics and Finance; 8(12); 2016.

NDIC (2011). Press briefing by Nigeria Deposit Corporation, on Resolution of failing banks through the establishment of bridge banks.

NDIC Publication (2018). Titled, AMCON, Bridge bank, Capitalization, Polaris, Resolution, Skye Bank.

Nethercott, L. \& Anamourlis, T. (2009). Impairment of Assets: A Tax Accounting Interface in Australia. Journal of Law and Financial Mangement - 8(1)

Nurdiansyah, D. \& Manda, G. (2018). The effect of allowance for bad debt loss to the level of profitability (case study in local bank Indonesia). Journal of Economics 6(1), 2018

Nyarko-Baasi, M. (2018). Effects of non-performing loans on the profitability of commercial banks - a study of some selected banks on the Ghana stock exchange

Okoye, L., Evbuomwan, G., Achugamonu, U., and Araghan, I. (2014). Impact of corporate governance on the profitability of the Nigerian banking sector. Esut Journal of Accountancy, 7(1), 2016.

Ojo, J. A. T., \& Somoye, R. O. C. (2013). The impact of commercial banks non-performing loans on financial development in Nigeria.

Olaleye, M. O., Agboola, J. O., Solomon, A. Z., \& Oyerogba, E. O., (2014). Financial reporting and compliance of impairment of non-current assets in the Nigerian banks. European Journal of Accounting Auditing and Finance Research 2(2), pp.18-35, April 2014.

Ozurumba, B. A. (2016). Impact of non-performing loans on the performance of selected commercial Banks in Nigeria. Research journal of Finance and Accounting, 7(16), 2016. Retrieved from https://www.iiste.org

Pandey, I. M. (2007). Financial Management, ninth edition; vikas publishing house pvt ltd

PWC (2016). IFRS 9: Impairment of risk assets; implementation challenges and strategy, Price water house. Retrieved from https://financialquest.com/ifrs-9-impairment

Riaz, S., Furqan, M. \& Siddique, S.S. (2015). Advertising influence on the profitability of public and private sector commercial banks in Pakistan. Bus Eco Journal 7: 191. doi:10.4172/2151-6219.1000191

Sooriyakumaran.L, \& Velnampy.T, (2013). Disclosures and impacts of impairment of noncurrent assets in the financial statements: A study on listed manufacturing companies in Colombo Stock Exchange (CSE) in Sri Lanka, Merit Research Journal of Accounting, Auditing, Economics and Finance 1(6) pp. 122-133.

Sooriyakumaran, L. \& Velnampy, T. (2014). Impact of impairment loss on profitability and capital structure of listed manufacturing companies in Sri-Lanka. Retrieved from https://papers.ssrn.com/sol3/papers 
Sufian, F \& Chong, R. R. (2008). Determinant of bank profitability in a developing economy: empirical evidence from the Philippines. Asian Academy of Management Journal of Accounting \& Finance. 4(2), 91-112

Tarko, S.C. W. (2015). Impart of non- performing loans on banks profitability in case of Dashen Bank, Ethiopia. A thesis submitted to the school of graduate studies of Saint Mary's in partial fulfillment of the requirements for the degree of Masters of Business Administration. Retrieved from http://Repository.smuc.edu.et/bitstream10

Trujillo- Ponce, A. (2013). What determine the profitability of banks? Evidence from Spain. Journal of Accounting \& Finance, 53(2), pp.561-586, 2013. Retrieved from https://ssrn.com/abstract=2260630

Ton, Z. (2009). The effect of labour on profitability: the role of quality in Boston. Harvard Business School Working Paper. Boston, MA 02163

Tan, A. Y. \& Floros, C. (2012). Bank profitability and inflation: the case of China. Journal of Economic Studies, 39 (6). pp. 675-696. ISSN 0144-3585

Uwuigbe, U., Uwuigbe, O. R. \& Oyewo, B. (2015). Credit management and bank performance of listed banks in Nigeria. Journal of Economics and Sustainable development ISSN 22221700 (Paper) ISSN 2222-2855 (Online) 6(2), 2015

Zimmerman, J. L. \& Watts, R. L. (1990). Positive Accounting Theory. A ten years perspective. The Accounting Review; Jan 1990; 65(1) pg. 131.Prentice Hall, Inc. Englewood Cliffs, New Jersey

\section{Copyrights}

Copyright for this article is retained by the author(s), with first publication rights granted to the journal. This is an open-access article distributed under the terms and conditions of the Creative Commons Attribution license (http://creativecommons.org/licenses/by/4.0/). 